\section{EFFICIENCY OF KINESIO TAPING IN PREVENTION AND REHABILITATION OF SPORT INJURIES}

EFIKASNOST KINEZI TRAKA U

PREVENCIJI I REHABILITACIJI SPORTSKIH POVREDA

\section{SUMMARY}

Kinesio Tape is becoming more widely used in sports physiotherapy and for postural rehabilitation. Many professional athletes use the tape to support injured, fatigued, or overused muscles. The tape's construction is unique, featuring a highly elastic property that engages both the muscles and fascia. It is claimed that KT supports injured muscles and joints and helps relieve pain by lifting the skin and allowing improved blood and lymph flow. The aim of this review was to evaluate, using meta-analysis, the effectiveness of $K T$ in the treatment and prevention of sports injuries. Electronic databases including SPORTDiscus, Scopus,MEDLINE, ScienceDirect and sports medicine websites were searched using keywords 'kinesio taping/tape'. The efficacy of KT in pain relief was trivial given there were no clinically important results. There were inconsistent ranges of motion outcome results, with at least small beneficial results seen in two studies, but trivial results in two other studies across numerous joint measurements. There was a likely beneficial effect for proprioception regarding grip force sense error, but no positive outcome for ankle proprioception. KT had some substantial effects on muscle activity, but it was unclear whether these changes were beneficial or harmful. In conclusion, there was little quality evidence to support the use of KT over other types of elastic taping in the management or prevention of sports injuries. KT may have a small beneficial role in improving strength, range of motion in certain injured subjects and force sense error compared with other tapes, but further studies are needed to confirm these findings.

Key words: sport medicine, kinesitherapy, recovery, atrophy
Bojan Ilić ${ }^{1}$, Aleksandra Nikolić ${ }^{2}$ and Dejan Ilić ${ }^{1}$

${ }^{1}$ Educational system Ruđer Bošković, Belgrad, Serbia

${ }^{2}$ Faculty of Sport and Physical Education, University of Belgrad, Serbia

Review scientific paper doi:10.5550/sgia.171301.en.INI UDC: 796:615.8

Received: 04.05.2017. Accepted: 21.06.2017.

Correspondence author:

Dejan Ilić, PhD Faculty of Sport and Physical Education

University of Belgrade Blagoja Parovića 156 11030 Belgrade Serbia

Tel:+381(11)3531-000 dejan.ilic@,fsfv.bg.ac.rs

Sportlogia 2017, 13 (1), 53-65. E-ISSN 1986-6119 COBISS.RS-ID 6769432 


\section{INTRODUCTION}

Taping is widely used to prevent injury to athletes (Thelen, Dauber \& Stonerman, 2008). Kinesio tape, invented by Kenzo Kase in 1996, is a new application of adhesive taping (Liu, Chen, Lin, Huang \& Sun, 2007). It is claimed that KT supports injured muscles and joints and helps relieve pain by lifting the skin and allowing improved blood and lymph flow (Kahanov, 2007). Tape is used to treat anything from headaches to foot problems and everything in-between. Examples include rehabilitation from sports injuries, carpal tunnel syndrome, lower back strain/pain (subluxation, herniated disc), knee and shoulder conditions, and many more (Lim, Park \& Bae, 2013).

According to the KT training manual (Kase \& Wallis, 2002), KT is highly stretchable (up to $75 \%$ of its original length) and its working mechanism is based on the taping direction and tension. Kase described KT applications for both "muscle facilitation" and "muscle inhibition" technique. KT applying from the muscle origin to insertion with stronger tension i.e. $50-75 \%$ of its original length may enhance muscle contraction (Kase, K., Wallis \& Kase, T. 2003). On the contrary, muscle contraction may be reduced by applying KT from the muscle insertion to origin with weaker tension i.e. $15 \%-25 \%$ of its original length (Kase, K., Wallis \& Kase, T. 2003).

There are many proposed benefits of KT including proprioceptive facilitation (Halseth, T., McChesney, J.W., DeBeliso, M., Vaughn, R. i Lien, J. 2004; Jaraczewska \& Long, 2006; Riemann \& Lephart, 2002), muscle facilitation (Hammer, 2006), reduced muscle fatigue, reduced delayed-onset muscle soreness (Nosaka, 1999), pain inhibition (Kahanov, 2007; Kneeshaw, 2002), enhanced healing such as reducing oedema, improvement of lymphatic drainage and blood flow (Kase, Hashimoto \& Tomoki, 1998; Kinesio Holding Corporation, 2008; Lipinska, Sliwinski, Kiebzak, Senderek \& Kirenko, 2007; ZajtKwiatkowska, Rajkowska-Labon, Skrobot, Bakula \& Szamotulska, 2007).

Furthermore, Dr. Kenzo Kase claimed that one of the effects of KT is to increase muscle strength (Kase, K., Wallis \& Kase, T. 2003). KT can facilitate muscle activity through concentric pull of the fascia, if applied from muscle origin to it's insertion (Hammer, 2006). KT can be applied literally on every human joint or muscle. However, there is no enough evidence which would advocate the use of $\mathrm{KT}$ in the treatment and rehabilitation after injuries. Limited number of studies, concerning the use of KT, show that KT might be use in order to enhance functions of human locomotion. In addition, KT can help in reducing pain, then, increasing stability and proprioception in patients with acute dislocation of patella, stroke, pain in joints and in states of trunk dysfunction.

These information come from series of studies and pilot studies thereby representing lower levels of clinical evidence. It seems that KT might be useful toll in rehabilitation and treatment of injured anthletes, but there is no enought studies to confirt that statement.

\section{METHODS}

Cochrane Collaboration review methodology (literature search, assessment of study quality, data collection of study characteristics, analysis and interpretation of results, recommendations for clinical practice and further research) was used to evaluate the effectiveness of KT in the treatment and prevention of sports injuries. Electronic data bases including SPORTDiscus,Scopus, MEDLINE, ScienceDirect, and sports medicine websites were searched using keywords 'kinesio taping/tape'. Of the 96 articles sourced ten studies

Ilić, B. et al.: Efficiency of kinesio taping... Sportlogia 2017, 13 (1), 53-65. Page 54. 
were used for meta-analysis using the following inclusion/exclusion criteria: (i) the article reported data for effect of KT on a musculoskeletal outcome (e.g. pain, range-of-motion, proprioception); (ii) the article had a KT group and a comparison group (e.g. KT applied without tension, placebo taping, no taping); and (iii) the full version was available in English.

The quality of the ten papers that met our inclusion/exclusion criteria was assessed based on the following key components of the methodological quality: (i) randomization of subject allocation; (ii) blinding of subjects; and (iii) blinding of all assessors. These criteria have been identified as being fundamental in reducing bias in clinical trials. For the ten studies included, data were extracted including participants' characteristics, study design, methodological quality, interventions, outcome measures and results (see table I).

A number of outcome measures were used to evaluate the effectiveness of KT, including strength, pain, range of movement, proprioception and muscle activity. We analyzed all statistically significant results reported within the ten studies, and made clinical inferences regarding the true value of their effects in a manner outlined by Batterham and Hopkins. Results that were not reported as being statistically significant were also assessed (where sufficient data were provided), and any results found to be of benefit in our analysis are discussed within the following sections.

\section{RESULTS}

An overview of details of the ten studies metaanalysed are summarized in table I. Tables II and III summarize the reported positive statistical results of KT, and our interpretation of the magnitudes of the effects and their clinical importance. Eight studies reported a statistically significant positive outcome for at least one outcome measure.

Table I. Characteristics of studies which studied the effectiveness of kinesio taping (KT) on strength, pain, range of motion (ROM), proprioception or muscle activity

\begin{tabular}{|c|c|c|c|c|}
\hline Study & $\begin{array}{c}\text { Study } \\
\text { quality }\end{array}$ & Study aim & Study design & Subject characteristics \\
\hline $\begin{array}{l}\text { Thelen, Dauber i } \\
\text { Stonerman, } 2008\end{array}$ & 4 & $\begin{array}{l}\text { Effect of KT vs sham treatment } \\
\text { on pain and ROM }\end{array}$ & $\begin{array}{l}\text { Randomized, blinded } \\
\text { clinical trial }\end{array}$ & $\begin{array}{l}\text { Control group: } 20-2 \mathrm{y} \text {, } \\
17 \mathrm{M}, 4 \mathrm{~F} \text {. } \\
\text { Experimental group: } \\
21-2 \mathrm{y} ; 19 \mathrm{M}, 2 \mathrm{~F} \text {. } \\
\text { All patients clinically } \\
\text { diagnosed with } \\
\text { rotator cuff } \\
\text { tendonitis/impingemnt } \\
\text { Control group: } 32-7 \mathrm{y} \text {; }\end{array}$ \\
\hline $\begin{array}{l}\text { GonzaLez-Iglesias et } \\
\text { al., } 2009\end{array}$ & 4 & $\begin{array}{l}\text { Effect of KT vs sham treatment } \\
\text { on neck pain and cervical ROM } \\
\text { in individuals with acute } \\
\text { whiplash-associated disorders }\end{array}$ & $\begin{array}{l}\text { Randomized, blinded } \\
\text { clinical trial }\end{array}$ & $\begin{array}{l}10 \mathrm{M}, 10 \mathrm{~F} . \\
\text { Experimental group: } \\
33-6 \mathrm{y} ; 10 \mathrm{M}, 11 \mathrm{~F} \text {. } \\
\text { All patients reported } \\
\text { neck pain as a result } \\
\text { of a motor accident }\end{array}$ \\
\hline Hsu et al., 2009 & 3 & $\begin{array}{l}\text { Effect of KT vs placebo taping } \\
\text { on kinematics, muscle activity } \\
\text { and strength of the scapular } \\
\text { region in baseball players with } \\
\text { shoulder impingement }\end{array}$ & $\begin{array}{l}\text { Randomized } \\
\text { crossover, pre- and } \\
\text { post-test repeated } \\
\text { measures design. } \\
\text { Examiners were } \\
\text { blinded }\end{array}$ & $\begin{array}{l}17 \text { amateur baseball } \\
\text { players with shoulder } \\
\text { impingement: } 23-3 y\end{array}$ \\
\hline Chang et al., 2010 & 3 & $\begin{array}{l}\text { Effect of KT vs placebo and } \\
\text { notaping on maximal grip strength } \\
\text { and force sense of healthy } \\
\text { collegiate athletes }\end{array}$ & $\begin{array}{l}\text { Randomized, blinded } \\
\text { repeated measures } \\
\text { design with single } \\
\text { group }\end{array}$ & $\begin{array}{l}21 \text { healthy collegiate } \\
\text { athletes: } 21-3 y\end{array}$ \\
\hline Vithoulka et al., 2010 & 2 & $\begin{array}{l}\text { Effect of KT vs placebo and } \\
\text { notaping on quadriceps strength }\end{array}$ & $\begin{array}{l}\text { Randomized repeated } \\
\text { measures design }\end{array}$ & $\begin{array}{l}20 \text { healthy nonathlete } \\
\text { F: } 27-4 y\end{array}$ \\
\hline
\end{tabular}

Ilić, B. et al.: Efficiency of kinesio taping... Sportlogia 2017, 13 (1), 53-65. Page 55. 


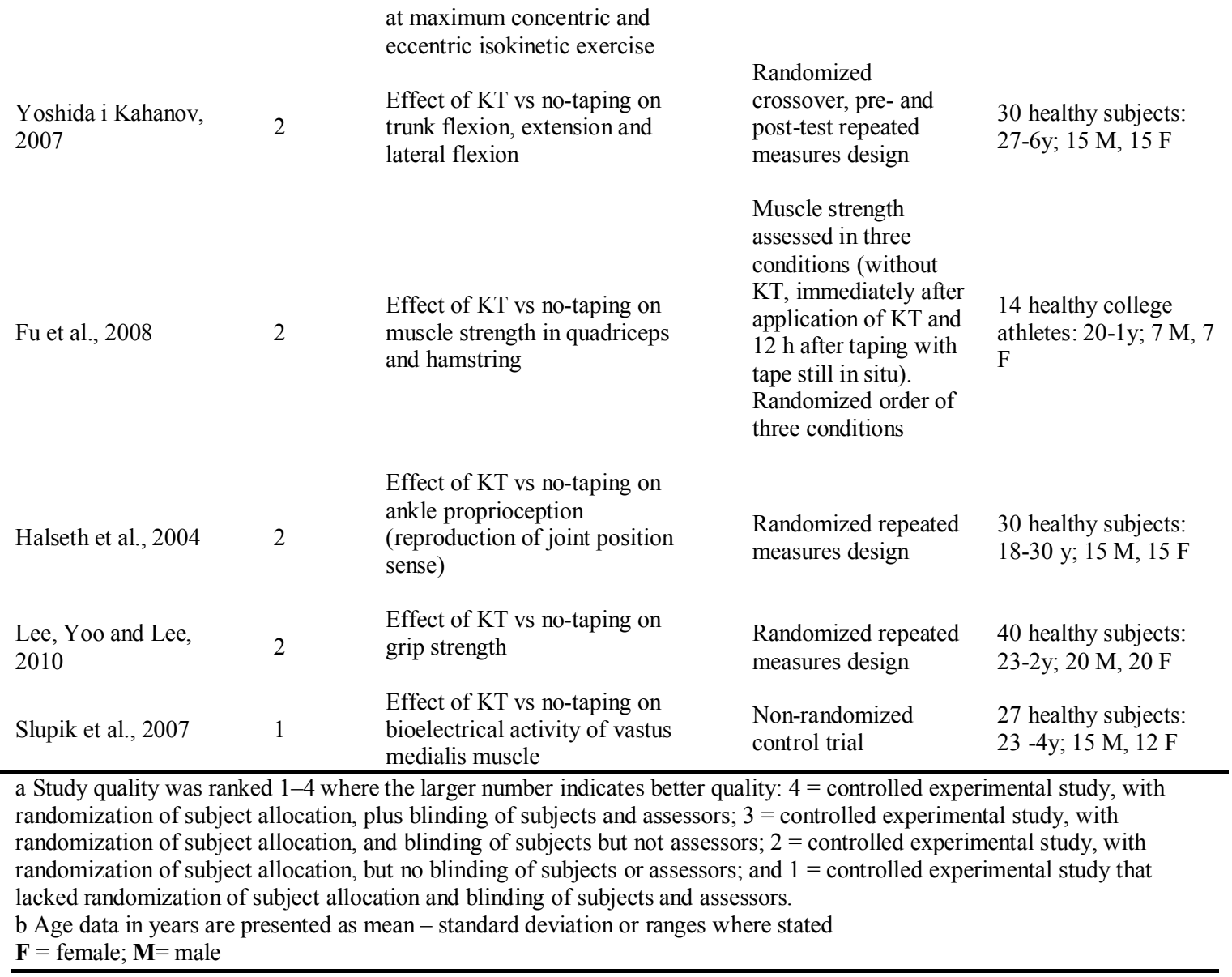

Table II. The effects of kinesio tape on range of motion

\begin{tabular}{|c|c|c|c|c|}
\hline Study & Outcome measure & Treatment comparison & Reported positive outcome & $\begin{array}{c}\text { Smallest } \\
\text { beneficial } \\
\text { difference }\end{array}$ \\
\hline $\begin{array}{l}\text { Thelen, Dauber i } \\
\text { Stonerman, } 2008\end{array}$ & ROM & KT vs placebo treatment & $\begin{array}{l}19.1 \pm 10.8^{\circ} \text { (pain-free shoulder } \\
\text { abduction; day } 1 \text { ) }\end{array}$ & $15^{\circ}$ increase \\
\hline \multirow[t]{7}{*}{$\begin{array}{l}\text { GonzaLez-Iglesias } \\
\text { et al., } 2009\end{array}$} & ROM & KT vs placebo treatment & $\begin{array}{l}6.6 \pm 1.1^{\circ} \text { (cervical flexion } \\
\text { immediate post) }\end{array}$ & $9.6^{\circ}$ increase \\
\hline & & & $7.4 \pm 1.8^{\circ}$ (cerv. flexion $\left.24 \mathrm{~h}\right)$ & $9.6^{\circ}$ increase \\
\hline & & & $\begin{array}{l}8.2 . \pm 1.7^{\circ} \text { (cerv. Extension } \\
\text { immediate post) }\end{array}$ & $7.0^{\circ}$ increase \\
\hline & & & $8.5 \pm 2.0^{\circ}$ (cerv. extension $\left.24 \mathrm{~h}\right)$ & $7.0^{\circ}$ increase \\
\hline & & & $\begin{array}{l}5.4 \pm 1.3^{\circ} \text { (cerv.right lateral } \\
\text { flex.immediate post) }\end{array}$ & $5.9^{\circ}$ increase \\
\hline & & & $\begin{array}{l}5.8 \pm 1.5^{\circ} \text { (cerv.right lateral flex. } \\
24 \mathrm{~h} \text { ) }\end{array}$ & $5.9^{\circ}$ increase \\
\hline & & & $\begin{array}{l}3.1 \pm 1.9^{\circ} \text { (cerv.left lateral } \\
\text { flex.immediate post) }\end{array}$ & $9.1^{\circ}$ increase \\
\hline
\end{tabular}




\begin{tabular}{|c|c|c|c|c|}
\hline & & & $\begin{array}{l}2.3 \pm 1.9^{\circ} \text { (cerv.left lateral flex. } \\
24 \mathrm{~h} 24 \mathrm{~h})\end{array}$ & $9.1^{\circ}$ increase \\
\hline & & & $\begin{array}{l}5.5 \pm 1.5^{\circ} \text { (cerv.right rotation } \\
\text { immediate) }\end{array}$ & $7.6^{\circ}$ increase \\
\hline & & & $\begin{array}{l}6.1 \pm 1.8^{\circ} \text { (cerv.right rotation } \\
24 \mathrm{~h})\end{array}$ & $7.6^{\circ}$ increase \\
\hline & & & $\begin{array}{l}5.2 \pm 1.4^{\circ} \text { (cerv.left rotation } \\
\text { immediate) }\end{array}$ & $6.7^{\circ}$ increase \\
\hline & & & $4.1 \pm 1.5^{\circ}$ (cerv.left rotation $\left.24 \mathrm{~h}\right)$ & $6.7^{\circ}$ increase \\
\hline \multirow[t]{2}{*}{ Hsu et al., 2009} & ROM & KT vs placebo treatment & $\begin{array}{l}1.1 \pm 0.7^{\circ} \text { (posterior tilt at } 30^{\circ} \\
\text { humeral elevation) }\end{array}$ & $1.2^{\circ}$ increase \\
\hline & & & $\begin{array}{l}1.2 \pm 0.8^{\circ} \text { (posterior tilt at } 60^{\circ} \\
\text { humeral elevation) }\end{array}$ & $1.2^{\circ}$ increase \\
\hline $\begin{array}{l}\text { Yoshida i Kahanov, } \\
2007\end{array}$ & ROM & KT vs no taping & $17.8 \pm 14.8 \mathrm{~cm}$ (trunk flexion) & $\begin{array}{l}6.37 \mathrm{~cm}(10 \% \\
\text { increase no } \\
\text { taping) }\end{array}$ \\
\hline
\end{tabular}

$\mathbf{K T}=$ kinesio tape $\mathbf{R O M}=$ range of motion; $\mathbf{C e r v} .=$ cervical

Table III. The effects of kinesio tape on pain, proprioception, strength and muscle activity

\begin{tabular}{|c|c|c|c|c|}
\hline Study & $\begin{array}{l}\text { Outcome } \\
\text { measure }\end{array}$ & Treatment comparison & Reported positive outcomes & $\begin{array}{l}\text { Smallest } \\
\text { beneficial } \\
\text { difference }\end{array}$ \\
\hline $\begin{array}{c}\text { GonzaLez-Iglesias et } \\
\text { al., } 2009\end{array}$ & Pain & $\mathrm{KT}$ vs placebo treatment & $\begin{array}{c}0.9 \pm 0.2 \text { (NPRS immediate } \\
\text { post-treatment) } \\
1.1 \pm 0.3 \text { (NPRS } 24 \text { h post- } \\
\text { treatment) }\end{array}$ & $\begin{array}{l}\text { 2-point reduction } \\
\text { 2-point reduction }\end{array}$ \\
\hline Chang et al., 2010 & Proprioception & KT vs placebo treatment & $\begin{array}{l}2.5 \pm 2.1 \mathrm{~kg} \\
3.3 \pm 2.7 \mathrm{~kg}\end{array}$ & $\begin{array}{l}0.44 \mathrm{~kg} \\
0.84 \mathrm{~kg}\end{array}$ \\
\hline Hsu et al., 2009 & Strength & KT vs placebo treatment & $\begin{array}{c}1.2 \pm 1.0 \mathrm{~kg} \text { (handgrip strength } \\
\text { change) }\end{array}$ & $0.70 \mathrm{~kg}$ \\
\hline Lee et al., 2010 & Strength & KT vs no taping & $\begin{array}{c}2.9 \pm 2.4 \mathrm{~kg} \text { (handgrip strength } \\
\text { change in males) } \\
1.6 \pm 1.3 \text { (handgrip strength } \\
\text { change in females) }\end{array}$ & $1.6 \mathrm{~kg}$ \\
\hline Vithoulka et al., 2010 & Strength & KT vs placebo treatment & $\begin{array}{l}1.96 \pm 4.9 \mathrm{Nm} \text { (quadriceps peak } \\
\text { torque at } 60 \% \mathrm{~s} \text { during } \\
\text { eccentric exercise) } \\
9.88 \pm 7.3 \mathrm{Nm} \text { (quadriceps peak } \\
\text { torque at } 60 \% \text { during } \\
\text { eccentric isokinetic exercise) }\end{array}$ & $8.33 \mathrm{Nm}$ \\
\hline Fu et al., 2008 & Strength & KT vs no-taping & $\begin{array}{l}3.2 \pm 1.7 \mathrm{~kg} / \mathrm{m} \text { (peak torque } \\
\text { during concentric contraction } \\
\text { of the quadriceps at } 180^{\circ} \mathrm{s} \text { ) }\end{array}$ & $2.12 \mathrm{~kg} / \mathrm{m}$ \\
\hline \multirow[t]{2}{*}{ Hsu et al., 2009} & $\begin{array}{l}\text { Muscle } \\
\text { activity }\end{array}$ & KT vs placebo treatment & $\begin{array}{c}14.2 \pm 11.7 \text { (increase in lower } \\
\text { trapezius muscle activity at } \\
60-30^{\circ} \text { humeral elevation) }\end{array}$ & $10 \%$ change \\
\hline & & & $23.0 \pm 19.8 \%$ (decrease in & $10 \%$ change \\
\hline Ilić, B. et al.: $\mathrm{B}$ & ficiency of $\mathrm{k}$ & esio taping... Sportlo & a $2017,13(1), 53-65 . P a g$ & 57. \\
\hline
\end{tabular}




\section{DISCUSSION}

Kinesio taping is a technique which uses the application of an elastic adhesive tape on the skin. KT is manufactured with elastic cotton which can be stretched from 120 to $140 \%$ its original length. It is used to pressurize the skin to affect the somato--sensory system under the areas where the tapes are applied (Kase \& Wallis, 2002). Compared with conventional tape, it is suggested that KT allows a greater range of motion and can be worn for longer periods of time without the need for reapplication (Kase \& Wallis, 2002). The proposed benefits of KT include facilitating joint and muscle realignment by strengthening weakened muscles (Kase \& Wallis, 2002), improving circulation of blood and lymph by increasing the interstitial space between the skin and underlying connective tissues (allowing for increased circulation of both venous and lymphatic fluid), (Kase \& Wallis, 2002)decreasing pain through the reduction in pressure on nociceptors, repositioning subluxed joints by relieving abnormal muscle tension, helping to return the function of fascia and muscle (Kase \& Wallis, 2002), and increasing proprioception through the stimulation of cutaneous mechanorectors. KT can be applied literally on every human joint or muscle. However, there is no enough evidence which would advocate the use of KT in the treatment and rehabilitation after injuries. Limited number of studies, concerning the use of KT, show that KT might be use in order to enhance functions of human locomotion. In addition, KT can help in reducing pain, then, increasing stability and proprioception in patients with acute dislocation of patella, stroke, pain in joints and in states of trunk dysfunction.

It is claimed that KT reduce pain by stimulation of sensitive neural pathways, i.e. by increasing afferented feedback information. The proposed mechanism in which KT reduce pain is by reducing afferent impulses which come from nocioceptors. In addition, KT lifts the skin thereby decreasing the pressure on mechanoreceptors of skin. Form 10 assessed studies, only the study of (GonzáLez-Iglesias, Fernández-de-las-Peñas, Cleland, Huijbregts \& Gutiérrez-Vega, 2009) reported statistically significant results for a measurement of pain. They noticed significant reduction of pain on a numerical pain rating scale (NPRS) in the KT group versus the sham treatment group for patients with acute whiplash-associated disorders.

One of proposed mechanism by which KT can increase range of motion is by increase of blood flow into the skin area which is covered with tape; physiological change which facilitate initiation of muscle movement. Additional theory is that fear is associated with intensity of pain in patients and so the application of KT provides sensory feedback that reduces fear of movement and thus increases range of motion (GonzáLez-Iglesias, Fernándezde-las-Peñas, Cleland, Huijbregts \& Gutiérrez-Vega, 2009). Thelen, Dauber \& Stoneman (2008) assessed the range of pain-free shoulder abduction in patients diagnosed with rotator cuff impingement, defining a clinically meaningful change as a $15^{\circ}$ increase. Our clinical conclusion from these statements is that KT may have at least a small, useful short-term effect on the range of motion for certain joints in injured patients. Study of (GonzáLez-Iglesias, Fernández-de-las-Peñas, Cleland, Huijbregts \& Gutiérrez-Vega, 2009) assessed cervical motion in six directions both immediately post treatment and 24-hours post-treatment. They

Ilić, B. et al.: Efficiency of kinesio taping... Sportlogia 2017, 13 (1), 53-65. Page 58. 
concluded that KT had a trivial effect on cervical range of motion for the vast majority of cervical motions, both acutely and 24-hours post-treatment.

Hsu, Chen, Lin, Wang \& Shih (2009) investigated the effect of KT on shoulder kinematics in baseball players with shoulder impingement syndrome. The KT group had statistically significant improvements in scapular orientations compared with the placebo group for posterior tilt at $30^{\circ}$ and $60^{\circ}$ of humeral elevation, but no other measures of scapular orientationsor displacements were statistically significant. Measurements at $30^{\circ}, 60^{\circ}$ and $90^{\circ}$ of posterior tilt of the scapular were also possibly beneficial in our analysis, despite being reported as statistically no significant by the authors. Our analysis found trivial or unclear differences for the 19 other measurements of scapular orientations. No beneficial effects were inferred for any of the 24 scapular displacement measurements, with possibly harmful effects found for eight measurements. KT may have beneficial effects on improving scapular kinematics in subjects with shoulder impingement syndrome, but only for specific degrees of humeral elevation. Overall, the effect of KT is likely to be trivial, or even possibly harmful for certain measurements, and therefore would not be recommended for use in treatment of shoulder impingement syndrome. Yoshida \& Kahanov (2007) assessed the effects of KT on trunk flexion, extension and lateral flexion in 30 healthy patients, using a randomized crossover design. There were positive changes for trunk flexion with a mean increase of 17.8 $\mathrm{cm}$ in the KT condition. However, the taping effect was not addressed given the comparison was a no-taping condition. The changes in lower trunk extension and lateral flexion were both nonsignificant, but the authors did not report specific p-values or confidence limits for us to make inferences about the magnitude of these results. The effect of KT on range of motion remains unclear because of the limited number of studies on a variety of joints, and the conflicting results. The beneficial effects of KT in the higher quality study conducted by (Thelen, Dauber \& Stoneman, 2008), suggested KT may have at least a small, useful shortterm effect on the range of motion for certain joints in injured cohorts. Beneficial effects were reported for cervical extension and right lateral flexion in patients with acute whiplashassociated disorders (GonzáLez-Iglesias, Fernández-de-las-Peñas, Cleland, Huijbregts \& Gutiérrez-Vega, 2009) and for certain aspects of scapular kinematics (Hsu, Chen, Lin, Wang i Shih, 2009). Regarding all these statements, we would not recommend the use of KT for the enhancement of range of motion in injured patients. In healthy patients there was at least a small beneficial effect for trunk flexion, as recorded in the study of (Yoshida \& Kahanov, 2007). However, given that placebo tapes were not used, we are not sure whether KT are useful or not comparing to traditional taping method.

It is proposed that KT may enhance muscle strength by initiating the concentric contraction of fascia which in turn stimulate, i.e. increase muscle contraction. KT might pull the skin or myofascia underneath the skin which helps release the tightened area of muscles and improve the flexibility (Lee J-H., Yoo \& Lee K-S., 2010). In addition, KT may facilitate muscle activity and improve muscle alignment which can contribute to marginal increases in muscle strength (Hsu, Chen, Lin, Wang \& Shih, 2009). Four of the ten studies reported positive outcomes in measures assessing strength. Study of (Lee J-H., Yoo \& Lee K-S., 2010) evaluate effect of KT on handgrip strength in 40 healthy subjects. Handgrip strength was significantly higher for both males and females when KT was applied to the flexor muscles of the dominant hand compared with the no-taping condition. Both results were calculated to be likely beneficial in our analysis, however, as there was no placebo taping condition, these results should be treated with caution.

Vithoulka, Beneka, Malliou, Aggelousis, Karatsolis \& Diamantopoulos (2010) investigated the effects of KT on quadriceps peak torque and reported a statistically significant increase for the KT condition during eccentric assessment. However, the significant differences were with regard to a one-way ANOVA result comparing KT, placebo

Ilić, B. et al.: Efficiency of kinesio taping... Sportlogia 2017, 13 (1), 53-65. Page 59. 
tape and no-taping conditions. However, study of Briem, Eythörsdöttir, Magnúsdóttir, Pálmarsson, Rúnarsdöttir \& Sveinsson (2011), which assessed the effect of KT on the level of activation of the fibularis longus muscle during a "sudden disturbance" of the ankle in 51 healthy athletes, did not find significant alterations in muscle strength. On the other hand Hsu, Chen, Lin, Wang \& Shih (2009), reported that KT application provoked a significant increase in the electromyography activity of the lower trapezius muscle during shoulder abduction in 17 athletes, underscoring that they exhibited shoulder impingement syndrome. Similar findings were reported by Firth, Dingley, Davies, Lewis \& Alexander (2010), who found no alteration in single-hop distance, in either healthy subjects or those with Achilles tendinopathy, after KT application to the ankle. Hwang-Bo \& Lee (2011) analyzed vertical hop height $30 \mathrm{~min}$ after KT application to the ankle, in healthy subjects, also finding no significant alteration. With respect to static balance Aytar, Ozunlu, Surenkok, Baltaci, Oztop \& Karatas (2011) detected an improvement during KT application to the femoral quadriceps in women with patellofemoral pain syndrome. Few studies have assessed lower limb function and one-footed static balance after KT application, hindering analysis of the real effects of this technique on these variables.In addition, study of Alano, Neto, Amorim, Macedo \& Brasileiro (2013) showed that KT application to $m$. rectus femoris, $m$. vastus lateralis and $m$. vastus medialis is not capable of altering lower limb function, one-footed static balance, peak knee extensor torque or activation amplitude of the VL muscle, in healthy women. Moreover, the application of nonelastic adhesive tape over the same area of skin did not significantly change these variables. Study of Fu, Wong, Pei, Wu, Chou \& Lin (2008) examined the effect of KT on muscle strength in healthy collegiate athletes. One statistically significant result was reported for the concentric contraction of the quadriceps at $180 \% \mathrm{sec}$ at 12 hours after taping, with tape still in situ.In contrast, Chang, Chou, Lin, J., Lin, C. \& Wang (2010) reported no statistically significant difference in maximal grip strength measured under three conditions (without taping, with placebo taping and with KT) in 21 healthy collegiate athletes. There was also one unclear and eight trivial results for measurements of strength, which preclude a clear conclusion being made. Further studies on similar muscles, and in particular KTs long-term effect on strength gain, warrant investigation.

There have been studies documenting a significant effect of the application of white athletic tape to the ankle on ankle proprioception (Karlsson \& Andreasson, 1992; Robbins, Waked \& Rappel, 1995; Heit, Lephart \& Rozzi, 1996; Simoneau, Degner, Kramper \& Kittleson, 1997). However, very little research has been done examining the effect alternative tape applications (such as that of Kinesio ${ }^{\mathrm{TM}}$ tape) may have on increasing cutaneous afference. Murray \& Husk (2001) examined the effect of kinesio taping on ankle proprioception. They concluded that kinesio taping for a lateral ankle sprain improved proprioceptive abilities in non-weight bearing positions in the midrange of ankle motion where ligament mechanoreceptors were inactive. Study of Chang, Chou, Lin, J., Lin, C. \& Wang (2010) examined the force sense error in grip strength measurements amongst 21 healthy collegiate athletes. They reported two positive results with respect to proprioception. Halseth, McChesney, DeBeliso, Vaughn, \& Lien (2004) also examined the effects of KT on ankle proprioception. The KT group showed no statistically significant change in absolute error for ankle reproduction of joint position sense measurements for both plantar flexion and inversion, when compared to the untapped condition. There were not enough data available for us to make clinical inferences regarding these results.

In order to fully understand the effect of Kinesio tape on proprioception, further research needs to be conducted on other joints, on the method of application of Kinesio ${ }^{\mathrm{TM}}$ tape, and the health of the subject to whom it is applied. Further research may provide vital information about a possible benefit of Kinesio ${ }^{\mathrm{TM}}$ taping during the acute and sub acute phases of rehabilitation, thus facilitating earlier return to activity participation. It is unclear

Ilić, B. et al.: Efficiency of kinesio taping... Sportlogia 2017, 13 (1), 53-65. Page 60. 
what direction of change in muscle activity represents a beneficial effect; a decrease may imply KT is having a supporting effect and the muscle is working more efficiently, while an increase could represent a facilitatory effect and enhanced muscle function (Hsu, Chen, Lin, Wang \& Shih, 2009). This is likely to be dependent on the specific muscle being assessed, the selected subjects (healthy or injured subjects) and the taping technique.Study of Lin, Hung \& Yang (2011) showed significant changes in EMG activity in the scapular muscles with the application of tape in the asymptomatic group. Proprioceptive feedback was also enhanced with taping. Thus, the mechanisms by which scapular taping can be explained are neuromuscular control as well as proprioceptive feedback factors. Morin, Tiberio \& Austin (1997) also found a significant decrease in muscle activity in the upper and middle trapezius region muscle with taping. Slupik, Dwornik, Bialoszewski \& Zych (2007) reported a $54 \%$ increase in muscle activity of the vastus medialis muscle 24 hours after application of KT. This effect was inferred to be most likely substantial. After 72 hours there was a $22 \%$ mean increase, compared with baseline values resulting in an effect we calculated to be very likely substantial.

Changes in muscle activity 10 minutes and 96 hours after KT application were both trivial. However, the order in which subjects were measured under the two conditions (with and without KT) was not performed in a crossover manner, and therefore the order effects were not controlled for. There was no placebo group, and so we were unable to ascertain whether changes were specifically due to KT, or simply the effect of taping alone. As a consequence, the results of this study must be questioned. In the study of GonzáLez-Iglesias, Fernández-de-las-Peñas, Cleland, Huijbregts \& Gutiérrez-Vega (2009) which investigate the impact of KT on muscle activity, KT was associated with a substantial change in muscle activity over specific ranges of humeral elevation. However, the majority of differences were trivial or unclear. Further research is required to determine whether the changes induced by KT were beneficial in the treatment of the injury.

\section{CONCLUSION}

The main purpose of our systematic review was to investigate effectiveness of KT in the treatment and rehabilitation of musculoskeletal injuries. The theory behind the use of KT is that the application of the tape improves lymphatic and blood circulation without restricting ROM and thus decreases pain, inflammation, and recovery times. Kinesio taping is attractive to active patients and high-level athletes looking for a therapeutic edge to improve outcomes, including performance, pain, function, and strength, following musculoskeletal injury.

We have searched electronic data bases including SPORTDiscus,Scopus, MEDLINE, ScienceDirect, and sports medicine websites, by typing keywords 'kinesio taping/tape'. Of the 96 articles sourced ten studies were used for meta-analysis. Two studies investigated sportrelated injuries (GonzáLez-Iglesias, Fernández-de-las-Peñas, Cleland, Huijbregts \& Gutiérrez-Vega, 2009; Hwang-Bo \& Lee, 2011), and only one investigated injuries in athletes (Hsu, Chen, Lin, Wang \& Shih, 2009).

Studies have shown that KT might be used in the prevention and treatment of musculoskeletal injuries (GonzáLez-Iglesias, Fernández-de-las-Peñas, Cleland, Huijbregts \& Gutiérrez-Vega, 2009; Hsu, Chen, Lin, Wang \& Shih, 2009; Hwang-Bo \& Lee, 2011; Kaya, Zinnuroglu \& Tugcu, 2010; Lee, 2015; Mostafavifar, Wertz \& Borchers, 2012; Thelen, Dauber \& Stoneman, 2008). KT may have a small beneficial effect on strength, force sense error and active range of motion of an injured area, but further clarification is needed (Williams, Whatman, Hume \& Sheerin, 2012). There was no substantial evidence to support

Ilić, B. et al.: Efficiency of kinesio taping... Sportlogia 2017, 13 (1), 53-65. Page 61. 
the use of KT for improvements in other musculoskeletal outcomes - pain, ankle proprioception or muscle activity (Williams, Whatman, Hume \& Sheerin, 2012).

Our systematic review found insufficient evidence for or against the use of KT to improve pain, function, performance following musculoskeletal injury. The number of high-quality, consistent studies available is limited, and this topic therefore warrants further research with higher levels of evidence, larger sample sizes, powered outcomes, and longer follow-up times to show the effect or lack thereof of KT. The implications of our review for current clinical practice are that KT is a safe modality, and that despite the lack of evidence to show a clinical benefit following musculoskeletal injury, the athlete may perceive a beneficial effect following KT application.

\section{REFERENCES}

Alano, C., Neto, F., Amorim, A., Macedo, L., \& Brasileiro, J. (2013). Kinesio taping does not alter neuromuscular performance of femoral quadriceps or lower function in healthy subjects: Randomized, blind, controlled, clinical trial. Manual Therapy, 18(1), 41-45.

https://doi.org/10.1016/j.math.2012.06.009 PMid:22796389

Aytar, A., Ozunlu, N., Surenkok, G. Baltaci, G., Oztop, P., \& Karatas, M. (2011). Initial effects of kinesio taping in patients with patellofemoral pain syndrome: a randomized, double-blind study. Isokinetics and Exercise Science, 19(2), 135-142.

Briem, K., Eythörsdöttir, H., Magnúsdóttir, R. Pálmarsson, R., Rúnarsdöttir, T., \& Sveinsson, H. (2011). Effects of kinesio tape compared with nonelastic sports tape and the untaped ankle during a sudden inversion perturbation in male athletes. Journal Orthopaedic and Sports Physical Therapy, 41(5), 328-335. https://doi.org/10.2519/jospt.2011.3501 PMid:21212501

Chang, H., Chou, K., Lin, J., Lin, C., \& Wang, C. (2010). Immediate effect of forearm Kinesio taping on maximal grip strength and force sense in healthy collegiate athletes. Physical Therapy in Sport, 11(4), 122-127. https://doi.org/10.1016/j.ptsp.2010.06.007 PMid:21055705

Firth, B., Dingley, P., Davies, E., Lewis, J., \& Alexander, C. (2010). The effect of kinesiotape on function, pain, and motoneuronal excitability in healthy people and people with achilles tendinopathy. Clinical Journal of Sport Medicine, 20(6), 416-421. https://doi.org/10.1097/JSM.0b013e3181f479b0 PMid:21079436

Fu, T., Wong, A., Pei, Y., Wu, K., Chou, S., \& Lin, Y. (2008). Effect of Kinesio taping on muscle strength in athletes-A pilot study. Journal of Science and Medicine in Sport, 11(2), 198-201. https://doi.org/10.1016/j.jsams.2007.02.011

PMid: 17588814

GonzáLez-Iglesias, J., Fernández-de-las-Peñas, C., Cleland, J., Huijbregts, P., \& Gutiérrez-Vega, M. (2009). Short-Term Effects of Cervical Kinesio Taping on Pain and Cervical Range of Motion in Patients With Acute Whiplash Injury: A Randomized Clinical Trial. Journal of Orthopaedic \& Sports Physical Therapy, 39(7), 515-521.

Ilić, B. et al.: Efficiency of kinesio taping... Sportlogia 2017, 13 (1), 53-65. Page 62. 
https://doi.org/10.2519/jospt.2009.3072

PMid: 19574662

Halseth, T., McChesney, J.W., DeBeliso, M., Vaughn, R., \& Lien, J. (2004). The effects of Kinesio taping on proprioception at the ankle. J Sports Sci \& Med, 3(1), 1-7. PMid:24497814 PMCid:PMC3896108

Hammer, W. (2006): Functional Soft-tissue Examination and Treatment by Manual Methods (3rd ed.). Boston, USA: Jones and Bartlett Publishers.

Heit, E., Lephart, S., \& Rozzi, S. (1996). The effect of ankle bracing and taping on joint position sense in the stable ankle. Journal of Sport Rehabilitation, 5, 206-213. https://doi.org/10.1123/jsr.5.3.206

Hsu, Y., Chen, W., Lin, H., Wang, W., \& Shih, Y. (2009). The effects of taping on scapular kinematics and muscle performance in baseball players with shoulder impingement syndrome. Journal of Electromyography and Kinesiology, 19(6), 1092-1099. https://doi.org/10.1016/j.jelekin.2008.11.003

PMid: 19147374

Hwang-Bo, G. \& Lee, J. (2011). Effects of kinesio taping in a physical therapist with acute low back pain due to patient handling: A case report. International Journal of Occupational Medicine and Environmental Health, 24(3), 320-323.

https://doi.org/10.2478/s13382-011-0029-8 PMid:21845524

Jaraczewska, E. \& Long, C. (2006). Kinesio taping in stroke: improving functional use of the upper extremity in hemiplegia. Topics in Stroke rehabilitation, 13, 31-42.

https://doi.org/10.1310/33KA-XYE3-QWJB-WGT6

PMid: 16987790

Kahanov, L. (2007). Kinesio taping, Part 1: An overview of its use in athletes. Athletic Therapy Today, $12,17-18$. https://doi.org/10.1123/att.12.3.17

Karlsson, J. \& Andreasson, G. (1992). The effect of external ankle support in chronic lateral ankle joint instability. An electromyographic study. Am J Sports Med., 20(3), 257-261. https://doi.org/10.1177/036354659202000304 PMid: 1636854

Kase, K., Hashimoto, T., \& Tomoki, O. (1996). Development of kinesio taping perfect manual. Kinesio Taping Association, 6(10), 117-118.

Kase, K., \& Wallis, J. (2002). The latest kinesio taping method. Tokyo, JPN: Ski-Journal.

Kase, K., Wallis, J., \& Kase, T. (2003). Clinical therapeutic applications of the Kinesio Taping method. Tokyo, JPN: Kinesio Taping Association.

Kaya, E., Zinnuroglu, M., \& Tugcu, I. (2010). Kinesio taping compared to physical therapz modalities for the treatment of shoulder impingement syndrome. Clinical Rheumatology, 30(2), 201-207. https://doi.org/10.1007/s10067-010-1475-6 PMid:20443039

Kinesio Holding Corporation (2008). Kinesio Taping Method Concepts. Retrived from http://kinesiotaping.com/kinesio-concept.php.

Kneeshaw, D. (2002). Shoulder taping in the clinical setting. Journal of Bodywork and Movement Therapies, 6, 2-8. https://doi.org/10.1054/jbmt.2001.0233

Lee, J.H., Yoo, W.G., \& Lee, K.S. (2010). Effects of head-neck rotation and Kinesio taping of the flexor muscles on dominanthand grip strength. J Phys Ther Sci, 22(3), 285-289. https://doi.org/10.1589/jpts.22.285

Lee, J. (2015). The Kinesio Taping technique may affect therapeutic results. Journal of Physiotherapy, 61(4), 231-232. https://doi.org/10.1016/j.jphys.2015.03.006 PMid:26093808

Lim, C., Park, Y., \& Bae, Y. (2013). The Effect of the Kinesio Taping and Spiral Taping on Menstrual Pain and Premenstrual Syndrome. Journal of Physical Therapy Science, 25(7), 761-764.

Ilić, B. et al.: Efficiency of kinesio taping... Sportlogia 2017, 13 (1), 53-65. Page 63. 
https://doi.org/10.1589/jpts.25.761

PMid:24259847 PMCid:PMC3820414

Lin, J., Hung, C., \& Yang, P. (2011). The effects of scapular taping on electromyographic muscle activity and proprioception feedback in healthy shoulders. J Orthop Res, 29(1), 53-57.

https://doi.org/10.1002/jor.21146

PMid:20607815

Lipinska, A., Sliwinski, Z., Kiebzak, W., Senderek, T., \& Kirenko, J. (2007). Influence of Kinesiotaping applications on lymphoedema of and upper limb in women after mastectomy. Polish Journal of Physiotherapy, 7, 258-269.

Liu, Y.H., Chen, S.M., Lin, C.Y., Huang, C.I., \& Sun, Y.N. (2007). Motion tracking on elbow tissue from ultrasonic image sequence for patients with lateral epicondylitis. Proceedings of the $29^{\text {th }}$ Annual International Conference of the IEEE EMBS Cité Internationale (pp. 95-98). Lyon, F. https://doi.org/10.1109/iembs.2007.4352231

Morin, G., Tiberio, D., \& Austin, G. (1997). The Effect of Upper Trapezius Taping on Electromyographic Activity in the Upper and Middle Trapezius Region. Human kinetics journal, 6(4), 309-318. https://doi.org/10.1123/jsr.6.4.309

Mostafavifar, M., Wertz, J., \& Borchers, J. (2012). A Systematic Review of the Effectiveness of Kinesio Taping for Musculoskeletal Injury. The Physician and Sportsmedicine, 40(4), 33-40. https://doi.org/10.3810/psm.2012.11.1986 PMid:23306413

Murray, H., \& Husk, L. J. (2001). Effect of Kinesio Taping on proprioception in the ankle. The Journal of Orthopaedic and Sports Physical Therapy, 31-37.

Nosaka, K. (1999). The Effect of Kinesio Taping on Muscular MicroDamage Following Eccentric Exercises. Paper presented at the 15th Annual Kinesio Taping International Symposium Review. (pp. 70-73). Tokyo, JPN. Kinesio Taping Association.

Riemann, B. L., \& Lephart, S. M. (2002). The sensorimotor system, part I: the physiologic basis of functional joint stability. Journal of Athletic Training, 37, 71-79. PMid:16558670 PMCid:PMC164311

Robbins, S., Waked, E., Rappel, R. (1995). Ankle taping improves proprioception before and after exercise in young men. Br. J. Sports Med., 29(4), 242-247.

https://doi.org/10.1136/bjsm.29.4.242

PMid:8808537 PMCid:PMC1332234

Simoneau, G. G., Degner, R. M., Kramper, C. A., \& Kittleson, K. H. (1997). Changes in ankle joint proprioception resulting from strips of athletic tape applied over the skin. Journal of Athletic Training,32, 141-147.

PMid:16558444 PMCid:PMC1319817

Slupik, A., Dwornik, M., Bialoszewski, D., \& Zych, E. (2007). Preliminary report. Ortop Traumatol Rehabil., 9(6), 644-651.

PMid: 18227756

Thelen, M.D., Dauber, J.A., \& Stoneman, P.D. (2008). The clinical efficacy of kinesio tape for shoulder pain: a randomized, doubleblinded, clinical trial. J Orthop Sports Phys Ther.,38(7), 389-395.

https://doi.org/10.2519/jospt.2008.2791 PMid: 18591761

Vithoulka, I., Beneka, A., Malliou, P., Aggelousis, N., Karatsolis, K., \& Diamantopoulos, K. (2010). The effects of Kinesio-Taping on quadriceps strength during isokinetic exercise in healthy non athlete women. Isokinetics and Exercise Science, 18(1), 1-6.

Williams, S., Whatman, C., Hume, P., \& Sheerin, K. (2012). Kinesio Taping in Treatment and Prevention of Sports Injuries. Sports Medicine, 42(2), 153-164.

https://doi.org/10.2165/11594960-000000000-00000 PMid:22124445

Winter, J. A., Allen, T. J., \& Proske, U. (2005). Muscle spindle signals with the sense of effort to indicate limb position. Journal of Physiology, 568, 1035-1046.

Ilić, B. et al.: Efficiency of kinesio taping... Sportlogia 2017, 13 (1), 53-65. Page 64. 
https://doi.org/10.1113/jphysiol.2005.092619

PMid:16109730 PMCid:PMC1464181

Yoshida, A., \& Kahanov, L. (2007). The Effect of Kinesio Taping on Lower Trunk Range of Motions. Research in Sports Medicine, 15(2), 103-112.

https://doi.org/10.1080/15438620701405206

PMid: 17578750

Zajt-Kwiatkowska, J., Rajkowska-Labon, E., Skrobot, W., Bakula, S., \& Szamotulska J (2007). Application of Kinesio taping for treatment of sports injuries. Medical Sports Press, 113, 130134.

\section{SAŽETAK}

Kinezi trake se sve više koriste u sportskoj fizioterapiji i posturalnoj rehabilitaciji. Mnogi profesionalni sportisti koriste trake kako bi podržali povređene, izmorene ili prekomerno iskorišćene mišiće. Konstrukcija trake je jedinstvena, ona poseduje visoko elastična svojstva koja angažuju i mišiće i fasciju. Veruje se da KT podržava povređene mišiće i zglobove kao i da oslobađa od bola tako što podiže kožu dozvoljavajući krvni i limfni protok. Cilj ovog preglednog članka je da evaluira, koristeći meta-analizu, efikasnost KT u tretmanu i prevenciji sportskih povreda. Elektronske baze podataka, poput SPORTDiscus, Scopus, MEDLINE, ScienceDirect i sajtovi sportske medicine su pretraživani koristeći ključne reči 'kinezi tejping/trake'. Efikasnost KT u oslobađanju od bola bila je beznalajna s obzirom da nije bilo klinički važnih rezultata. Što se tiče opsega pokreta, dobijeni su neusaglašeni rezultati sa malim korisnim rezultatima, zapaženim u dve studije, mada beznačajni rezultati u druge dve studije za brojne zglobove. Ostvaren je koristan efekat za propriocepciju po pitanju osećaja za grešku u testu sile stiska šake, mađutim, nije bilo pozitivnih efekata za propriocepciju skočnog zgloba. KT su ostvarile znatan efekat na mišićnu aktivnost, mada nije jasno da li su te promene bile korisne ili štetne. Da zaključimo, postoji jako malo kvalitetnih dokaza koji bi podržali korišćenje KT, u poređenju sa drugim tipovima elestičnih traka, $u$ upravljanju ili prevenciji sportskih povreda. KT mogu imati malu korisnu ulogu u poboljšanju sile, opsega pokreta kod određenih povređenih subjekata, kao i u poboljšanju osećaja za grešku, u poređenju sa drugim trakama, mada potrebna su dalja istraživanja koja bi to potvrdila.

Ključne reči: sportska medicina, kineziterapija, oporavak, atrofija

Ilić, B. et al.: Efficiency of kinesio taping... Sportlogia 2017, 13 (1), 53-65. Page 65. 